\title{
Assessment of Improving the Efficiency of Fire Extinguishing by Using Surface Active Agents
}

\author{
Georgij Kiselov, Vladimir Jemeljanov, Janis Ievinsh, Riga Technical University
}

\begin{abstract}
Fire causes considerable material damages to the ecology and environment as well as in a number of cases it is accompanied by human victims. No material goods can replace human life, therefore human life and safety always remain in the first place. Since fires potentially can cause a considerable damage, the fire safety and firefighting sphere are permanently developing in the world in order to improve the state of fire safety, reduce the risk of fires, successfully extinguish the fire and minimize the potential consequences. Since successful firefighting is closely associated not only with the level of fire-fighting equipment, extinguishing techniques, manufacturing and construction methods, building constructive solutions, but also to a large extent depends on efficiency of the extinguishing agents, the authors' aim is to study the efficiency improvement of water and its mixtures with surfactants. The article is based on the experiments, which were carried out under laboratory conditions, simulating Class $A$ and $B$ fires. A stationary automatic fire extinguishing system was used as the fire-fighting equipment with a sprinkler-type system, providing firefighting with a sprinkler, feeding extinguishing agents into a hotbed in a fine spray stream. In the practical experiment, foam concentrates of different producers, brands and types were used as surface-active substances and impurities which were added to water in different concentrations and combinations. The concentration of active surfactants in water directly affects fire-extinguishing properties of liquids, i.e., observing the amount of surfactants and water liquids one can achieve the reduction of the amount of water, which allows to reduce material loss connected with using water in fire extinguishing. However, an in-depth study must be carried out to find out how economically profitable is the use of SAA for fire extinguishing.
\end{abstract}

Keywords: fire extinguishing, efficiency, reaction zone, surface active agents, mixtures.

\section{Introduction}

Fire causes considerable material damage to ecology and environment; in a number of cases it is accompanied by human victims. No material goods can replace human life, therefore human life and safety always remain in the first place. Since fires potentially can cause considerable damage, the fire safety and firefighting sphere is permanently developing in the world in order to improve the state of fire safety, reduce the risk of fires, successfully extinguish the fire and minimize the potential consequences. Since successful firefighting is closely associated not only with the level of fire-fighting equipment, extinguishing techniques, manufacturing and construction methods, building constructive solutions, but also it depends on efficiency of the extinguishing agents, the authors' aim is to study the efficiency improvement of water and its mixtures with surfactants in automatic fire extinguishing systems with finely sprayed water by adding the foam agents.

The present work presents a statistical study where the number of fires, their impact on our everyday life, consequences, victims and losses are analysed. The first part of the study describes the fire disposal options from analytical and theoretical point of view, as well as the nature of the combustion process is examined revealing a wide range of firefighting horizons, showing the directions and techniques for quick and efficient extinguishing of fire, which is practically tested, summarizing the results. The practical part is based on the experiments, which were carried out under laboratory conditions, simulating Class A and B fires. A stationary automatic fire extinguishing system of sprinkler-type was used, providing firefighting with a sprinkler that delivers the extinguishing agent into a hotbed in a fine spray. In the practical experiment, foam concentrates of different producers, brands and types were used as the surface-active substances and admixtures added to the water in different concentrations and combinations. The work studies the regularities of extinguishing agents' admixtures, as well as mixture combination that can conceptually change the automatic fire-extinguishing system design. The firefighting principles have been developed for solid substances fires in open and hard-to-reach areas, considerably reducing the time of firefighting and the amount of required extinguishing agent (water), as well as significantly reducing the negative environmental impact.

\section{Theory of Combustion Heat}

To define the most rational techniques of improving fire fighting ability of water, one has to 
examine combustion and extinguishing mechanisms. According to the latest views, theory of extinguishing wood and other solid polymer materials is based on the theory of combustion heat. Main regularities are studied in the works of J.Zeldovich, D.FrankKamenetsky and others [12]. According to their research, to stop burning of wood or other solid polymer materials means to stop an exothermic reaction that takes place in a thin layer in the combustion zone (reaction zone). Wood, as one of the most wide-spread burning nature materials, burns in two regimes during the fire:

- Homogenous diffusive that defines the spread and development of fire;

- Heterogenous, when charred residues are completely burned.

At the stage of homogenous diffusive burning there takes place pyrolysis of wood, when volatile products are emitted. They mix up with air oxygen of burning zone and make burning mixture. This mixture, burning above wood surface, emits a significant amount of heat energy. Part of this energy comes to the surface of burning material, rising its temperature, intensifying the pyrolysis process and thus speeding up the process of burning until its stabilisation. On average, the parameters of burning material are the following [13]:

a) Wood surface temperature from $500-700{ }^{\circ} \mathrm{C}$;

b) Thickness of heated layer (until volatile substances emergence temperature from 200 $500{ }^{\circ} \mathrm{C}$ ) is about $1 \mathrm{~cm}$;

c) Speed of combustion from is from 0.008 to 0.01 $\mathrm{kg} / \mathrm{m}^{2} \mathrm{~s}$.

Flame temperature is $1000-1200{ }^{\circ} \mathrm{C}$, which creates heat emission on average equal to 225.7 $\mathrm{kJ} / \mathrm{m}^{2} \mathrm{~s}$.

In the reaction zone also combustion products are heated because of emitted heat. Simultaneously with these processes there takes place heat return process. Temperature stabilises in the reaction zone when the speed of heat emission $q_{1}$ gets balanced with heat return speed $q_{2}$. Consequently, there is heat balance in the reaction zone, but the temperature of the zone is combustion temperature and heat balance temperature. It is defined that combustion temperature of a substance is not a constant quantity, it varies depending on emitted and returned heat speed proportion. The speed of heat emission in diffusive combustion zone depends on many factors. At constant amount of oxygen in the air and in burning substance, the speed depends on diffusion speed of reactive substances in the reaction zone as well as on the combustion heat and the degree of burning polymer material complete combustion.

In diffusive combustion zone heat emission speed on zone reaction surface unit is the following:

$$
q_{1}=Q k_{s},(1.1 .)
$$

where: $k_{S}$ - amount of oxygen that reacted in a unit of time on reaction zone surface unit;

$Q$ - reaction heat effect.

Simultaneously with heat emission, in the reaction zone there takes place transfer of heat in convective way into environment and in radiant way from the reaction zone. Heat delivery speed $q 2$ depends on combustion temperature, gas temperature in the environment and corresponding heat exchange ratios:

$$
q_{2}=\alpha\left(T_{r}-T_{c}\right)+\theta \vartheta\left(T_{r} 4-\mathrm{TC}^{4}\right)
$$

where: $\quad \alpha-$ heat exchange ratio, $\mathrm{W} /\left(\mathrm{m}^{*} \mathrm{~K}\right)$;

$\mathrm{T}_{\mathrm{r}}$ - combustion temperature, $\mathrm{K}$;

$\mathrm{T}_{\mathrm{c}}$ - environment temperature, $\mathrm{K}$;

$\theta$ - reaction zone charring degree $(0.20-0.85)$;

$\vartheta$ - Stefan -Bolcman constant, $20.5 \mathrm{~kJ} /\left(\mathrm{m}^{* \mathrm{~K}}\right)$. $\mathrm{o}=5.670400(40) \times 10^{-8} \mathrm{Wm}^{-2} \mathrm{~K}^{-4}$ Bolcman constant

To extinguish burning wood or other solid burning material, it is necessary that heat removal speed would exceed heat emission speed. Then the maximum combustion temperature decrease according to J.Zeldovich research is $\frac{3 R T_{g}{ }^{2}}{E}$. Then cooling temperature $\mathrm{T}_{\mathrm{p}}$ is:

$$
T_{p}=T_{r}-\frac{3 R T}{E}
$$

where: $\mathrm{R}$ - universal gas constant; $\mathrm{E}$ - activation energy.

Combustion temperature can be made lower than extinguishing temperature by reducing heat emission speed. It can be achieved by various methods, but at least one of the below mentioned conditions should be observed:

a) to isolate combustion zone from air or reduce oxygen concentration to the level when combustion cannot happen;

b) to reduce the temperature of burning substances and materials below their flashpoint;

c) to cool reaction zone below defined cooling temperatures $\left(T_{p}\right)$;

d) to intensively slow down chemical reaction flames;

e) to liquidate flames mechanically with the help of strong gas or extinguishing substance jet;

f) to create conditions for fire blocking.

All fire-extinguishing substances have a combined effect on substance combustion process. But each fire-extinguishing substance has some characteristic dominating feature. Water as fireextinguishing substance mostly works in three kinds of extinguishing mechanisms: cooling burning materials and reaction zone, dilution of reaction zone with water vapours and isolation of burning material from reaction zone. Extinguishing of burning wood is 
now based mostly on its cooling below $200-250{ }^{\circ} \mathrm{C}$. Until extinguishing moment burning wood is heated to definite depth, and a surface charcoal layer is formed on it. Its thickness depends on free combustion time of the fire. The temperature of the upper layer can reach $500-700{ }^{\circ} \mathrm{C}$ [5]. The speed of heat supply to the depth of wood and, consequently, the speed of material combustion depends on surface charcoal layer temperature. So the main task of extinguishing is to reduce the surface charcoal layer temperature to the cooling temperature. Supplying water with a compact or sprinkled jet touches the burning wood surfac and forms a thin water layer, which on the one side comes into contact with the charcoal layer, but on the other side contacts heated gas and vapour that are in the combustion zone. That is why water layer simultaneously takes up the heat from wood charcoal $\left(q_{d}\right)$, gas $\left(q_{g}\right)$ and from combustion zone surface $\left(q_{2}\right)$;

$$
Q_{U}=q_{d}+q_{g}+q_{2},(1.4 .)
$$

Where: $\mathrm{Q}_{U}$ - heat taken by water during extinguishing process.

Water has high heat capacity and vapour forming heat; it intensively takes heat and forms vapour that dilutes burning substances in the reaction zone. Some very important for fire extinguishing physical water characteristics change at its heating. First of all, it applies to thermal conductivity, which from $1.791 \times 10$ $\mathrm{W} / \mathrm{m}$.degree at $45{ }^{0} \mathrm{C}$ reduces until $0.0639 \times 10$ $\mathrm{W} / \mathrm{m}$.degree at $100{ }^{\circ} \mathrm{C}$, which also changes water heat insulation properties. The most marked changes are in water viscosity depending on the temperature. From the analysis of mentioned changes in water characteristics it can be seen that water with low viscosity quickly drains from burning wood and a large part of it does not participate in extinguishing process. Consequently, water supply intensity and its consumption should be increased that causes certain problems during fire and it leads to the increase in fire extinguishing time and causes bigger material loss [1, $2,8]$. To compare real water consumption with theoretically necessary for extinguishing wood combustion process, we calculate the amount of water necessary for extinguishing $1 \mathrm{~m}^{2}$ of burning wood. The water is supplied as compact or spray jets. Dominating mechanism relatively is wood cooling until its decomposition temperature when volatile substances are emitted. Other factors like combustion zone cooling and dilution of burning mixture with water vapours are not taken in consideration.

Then necessary condition for combustion interruption will be:

$$
\mathrm{Q}_{\mathrm{U}}>\mathrm{Q}_{\mathrm{K}}
$$

where: $\mathrm{Q}_{\mathrm{U}}$ - amount of heat taken by water from burning wood, J.;
$Q_{K}$ - amount of heat taken by wood from combustion zone, $\mathrm{J}$;

$$
Q_{u}=S_{U} \delta_{U} \gamma_{U} C_{U} \Delta t_{U}+S u \delta_{U} \gamma_{U} r
$$

where: $S_{U}$ - water surface area on the material extinguished, $\mathrm{m}^{2}$;

$\delta_{U}$ - thickness of water layer, $\mathrm{mm}$;

$\gamma_{U}-$ specific weight of water, $\mathrm{kg} / \mathrm{m}^{3}$;

$C_{U}$ - specific heat capacity of water, $\mathrm{J} / \mathrm{kg}$;

$\Delta t_{U}$ - difference between boiling temperature and basic temperature of water, which is relatively taken as $20{ }^{\circ} \mathrm{C}$;

$\mathrm{r}$ - vapour forming hidden heat, $\mathrm{J} / \mathrm{kg}$;

$$
Q_{K}=S_{K} q_{p} \tau_{\mathrm{p}}+\mathrm{S}_{\mathrm{K}} \delta_{K} \gamma_{K} C_{K} \Delta t_{K},
$$

where: $S_{K}$ — burning wood area, $\mathrm{m}^{2}$;

$q_{p}$ - heat flow from the reaction zone to burning wood surface;

$\tau_{\mathrm{p}}$ — burning time (extinguishing), $\mathrm{s}$; $\gamma_{K}$ - specific weight of wood, W;

$C_{K}$ - heat capacity of wood;

$\Delta t_{K}$ - difference between maximum wood heating temperature and temperature to which it is cooled.

All quantities in the equations (1.6. and 1.7.) are known, except $\delta_{U}$. After relevant modification of the equations 1.5., .1.6. and 1.7. we get:

$$
\delta_{U=} \frac{q_{p} \tau_{p}+\delta_{K} \gamma_{K} C_{K} \Delta t_{K}}{\gamma_{U} C_{U} \Delta t_{U}+\gamma_{U} r}
$$

Because of extinguishing, heat radiation reduces from maximum to zero. We conditionally accept that the amount of heat taken by wood during extinguishing process is one half from the maximum. Taking into consideration that the temperature of heated wood layer is not homogenous and varies from $700-200{ }^{0} \mathrm{C}$, we conditionally accept temperature reduction while cooling the heated layer as $250{ }^{\circ} \mathrm{C}$. Then the necessary thickness of water layer at extinguishing time $10 \mathrm{~s}$ will be:

$$
\delta_{U} \approx 0.5 \mathrm{~mm}
$$

The assumptions introduced significantly simplify the real physical scene of extinguishing process. But the quantitative indicators acquired leave no doubt, as from the set of many extinguishing mechanisms only one, conditionally accepted as dominating, was chosen. While extinguishing, not only the extinguishing mechanism, but also the dilution mechanism with water vapours of the reaction zone is working, as evaporating 11 of water, 17001 of vapour are formed. But only a small part of vapour takes part in zone dilution, as the volume of 
the reaction zone is much smaller than the volume of vapour, and water vapour going through it, quickly leave the reaction zone. Water forms only $0.009 \mathrm{~mm}$ thick layer on the wood surface. This shortcoming of water as the means of extinguishing is proved by real specific water comsumption for fire extinguishing. It is shown in Table 1.

Specific Water Consumption in Fires $[3,5,7$.

\begin{tabular}{|l|l|c|c|c|}
\hline $\begin{array}{c}\text { Nr. } \\
\text { p.k. }\end{array}$ & \multicolumn{1}{|c|}{ Name of fire object } & $\begin{array}{c}\text { Fire area, } \\
\mathrm{m}^{2}\end{array}$ & $\begin{array}{c}\text { Total quantity of } \\
\text { water consumed, 1 }\end{array}$ & $\begin{array}{c}\text { Specific water } \\
\text { consumption, } \\
\text { 1/min. }\end{array}$ \\
\hline 1$)$ & Wooden house & 40 & 2,000 & 500 \\
\hline 2$)$ & $\begin{array}{l}\text { Furnishings } \\
\text { in a wooden house }\end{array}$ & 20 & 2,000 & 100 \\
\hline 3$)$ & $\begin{array}{l}\text { One-storey } \\
\text { wood-working shop, U3 } \\
\text { Fireproofness degree }\end{array}$ & 500 & 25,000 & 500 \\
\hline 4$)$ & $\begin{array}{l}\text { One-storey } \\
\text { Store for industrial goods } \\
\text { U3 Fireproofness degree }\end{array}$ & 40 & 16,000 & 400 \\
\hline
\end{tabular}

Slight actual water layer thickness on burning wood surface cannot be a safe insulating layer for heat energy effect from the reaction zone on burning material. Consequently, water flow rapidly down the burning surface, when a water jet is directed to another burning place, hot combustion products and flames from nearby burning wood repeatedly affect the area being extinguished. As a result, the temperature of extinguished area surface rises, combustion products start emitting again and combustion gets renewed. It can be prevented by a longer effect of water on wood and thickening its layer which neutralises the effect of heat factors in the time necessary for extinguishing burning surfaces. Extinguishing practice shows that such an approach is not justified and one has to search for improving the extinguishing capability of water. Due to the fact that the aim of the research is to improve the effectiveness of fire extinguishing, it is necessary to examine and simulate fire combustion and extinguishing processes in a more detailed way, analysing the effect of surface-active agents (further on - SAA) in the process of extinguishing.

\section{The Quantity of Water Mixture Use Ratio}

One of the positive characteristics of water is, first of all, its good transportation capacity and cheapness, convenient supply to the combustion zone, accessibility and wide distribution, so it becomes clear why water is the most favourable means of extinguishing. Inspecting all positive and negative characteristics of water closer, the shortcomings of water as means of extinguishing must be noted. High surface tension $\delta=72.53 \times 10^{-3} \mathrm{H} / \mathrm{m} 20{ }^{\circ} \mathrm{C}[9,2]$, low dynamic viscosity ratio $\eta=1 \times 10^{-6} \mathrm{~m}^{2} / \mathrm{s}$, high freezing temperature $t_{S}=0{ }^{0} \mathrm{C}$, high electric conductivity $4.41 \times 10^{-8} \Omega^{-1} \times \mathrm{cm}^{-1}$ at $18{ }^{0} \mathrm{C}$, chemical activity when facing alkali and alkali-earth metals, carbide and others, corrosive effect on metals and other materials reduces extinguishing effectiveness of water, efficiency ratio and restricts wider use of water.

Due to the fact that water has high surface tension and low dynamic viscosity ratio, it flows down the surfaces very quickly and almost is not absorbed in materials, but the electric conductivity of water does not allow using it without special protective equipment for fire extinguishing systems under voltage. High surface tension and low viscosity is of great importance, as exactly these parameters influence the amount of water consumption and extinguishing time. It is connected with material loss caused by fire, as well as large consumption of funds constructing internal firefighting water supply system with large diameter pipes. That is why it is very important to improve the fire-extinguishing efficiency of water.

To increase the efficiency ratio of water while fire-extinguishing, various types of "quenchers" are used in fire extinguishing practice for a long time. The use of quenchers reduced the necessary for fireextinguishing water consumption almost twice due to significant rise in absorption capacity. But further improvement of fire-extinguishing efficiency only with the use of quencher appeared impossible. Therefore, obviously, parallel to improving physical and chemical characteristics of water, water supply technique to the combustion zone, extinguishing tactics and other parameters defining the effect of extinguishing should be improved. But at the moment these hidden reserves for increasing the fire extinguishing efficiency of water with the help of quenchers are not implemented. At the moment any research in this direction is not done, because the colour of some materials changes irreversibly, when using quenchers, surface-active agents, for fire extinguishing, wood cannot be lacquered further on, interstorey flooring gets soaked much faster [9]. In the authors' opinion, two last fire influencing factors are not significant, but the last one indicates that the 
advantages provided by fire extinguishing with modified water using SAA divided into two groups are not fully used.

It is still supplied as previously using a lot of water in excess which drenches interstorey flooring and floods the storeys. To increase the extinguishing efficiency of water, the research on raising water viscosity was done for its greater adhesion to the surfaces extinguished. By raising water viscosity the thickness of water layer on the surface of burning materials grows and its cooling and insulation capacity grows.

The efficiency ratio of all energy systems (further on - ER) has been seriously studied for many years. Such research is being conducted at the moment as well. In our case ER is the water utilization ratio $\mathrm{K}_{\mathrm{i}}$, when extinguishing the fire $K_{i}$ increase research is connected with its so far low values that complicate the extinguishing process and cause great material loss. $\mathrm{K}_{\mathrm{i}}$ must be understood as proportion between the theoretically necessary amount of water $V_{t}$ for definite fire extinguishing and the actually consumed amount of water $V_{f}$. The amount of water necessary for extinguishing open solid combustion materials, including wood, is defined theoretically $\mathrm{K}_{\mathrm{i}}=\mathrm{V}_{\mathrm{t}} / \mathrm{V}_{\mathrm{f}}$. $\mathrm{K}$ is a non-dimensional value with multiple dependence that complicates its research. The reasons of these difficulties are both subjective and objective [11]. The factors defining $\mathrm{K}$ value can be shown as follows:

1. Efficiency of extinguishing material which depends on physical and chemical characteristics of a substance and the efficiency of its supply to combustion zone $\mathrm{K}_{1}$ method;

2. Nonsimultaneous supply of fire extinguishing substance to all the fire area (causes of subjective and objective character) $\mathrm{K}_{2}$;

3. Impossibility to supply extinguishing substance to some burning surfaces as there are hidden combustion surfaces $\mathrm{K}_{3}$;

4. Reserve ratio $\mathrm{K}_{4}$ and others.

The meaning of $K_{i}$ in fire-fighting practice is essential. The improvement reduces fire extinguishing time, raises extinguishing efficiency of water and its consumption, reduces material loss of all kind, allows to improve the culture and quality of extinguishing, but the main point is that safe work of firefighters in the process of fire-extinguishing is achieved. Processing statistic data on fires proves that $\mathrm{K}_{\mathrm{i}}$ is very low and is within 0.0012 to 0.0017 . Solving the problem about $\mathrm{K}_{\mathrm{i}}$, we solve also one of the most important questions of fire safety, i.e., the improvement of fire safety efficiency for people and national economy, improving the methods of fire extinguishing at minimum consumption and loss. On the basis of the above mentioned, a crucial role belongs to extinguishing substance to increase extinguishing efficiency, i.e., the efficiency ratio of using this substance which depends both on the efficiency of extinguishing substance fire extinguishing capacity and other reasons.

The authors in their article describe the research and practical work defining the mixture combinations where SAA are added in mixtures of different composition and manufacturers, increasing the extinguishing properties of water, so the objectives of the research are:

1. to calculate the necessary water specific consumption, extinguishing $\mathrm{A}$ and $\mathrm{B}$ class simulated fires;

2. to define average statistic $\mathrm{K}_{\mathrm{i}}$ value on the basis of the statistic analysis of real fire extinguishing results;

3. to define experimentally $\mathrm{V}_{\text {ip }}$ values for water in laboratory conditions without and with chemical additives, to define $K_{i}$ increase limits in fire fighting practice by extinguishing with water and water mixtures;

4. to evaluate the theoretical and practical results obtained to recommend effective extinguishing compositions for practical use in fire fighting in the Republic of Latvia.

\section{Assessment of Fire Extinguishing Efficiency Extinguishing Solid Combustible Materials}

The effectiveness of methods and techniques of ensuring fire safety is characterised by composite measures that have an organisational, preventive and technical character, as well as by efficiency of fire extinguishing techniques. To great extent the efficiency of techniques for stopping combustion process depends not only on the type and efficiency of extinguishing substance, but also on the efficiency of supplying technique for these substances to the combustion zone, the determinant direction chosen, effect of weather conditions, the amount of resources at the moment of arrival.

Extinguishing process is of dual character, so it is necessary to define the optimal parameters for fire extinguishing process and objective numeric indicators for its extinguishing efficiency. On the one hand, extinguishing process is a combination of technical, organisational and operatively tactic measures for ensuring a combat action directed at extinguishing and localisation of fire, but, on the other hand, it is the implementation of definite physical processes and phenomena that is subject to objective laws of physics and definite numerical regularities.

Discovering these regularities, defining functional links of these basic parameters and choosing process optimisation parameters allows to describe the set of phenomena numerically that exists during fire extinguishing and choose a favourable combination of these parameters. But this, in its turn, will allow, firstly, to significantly increase the efficiency and quality of fire extinguishing process and, along with it, reduce the danger of fire and the volume of 
material loss. Secondly, while extinguishing solid combustible material, it will allow to numerically assess the degree of consistency of numerical values for real fire extinguishing parameters to the optimal value, which in definite conditions can be considered as normative value for this parameter: normative supply intensity for extinguishing substances $J_{\text {nep. }}$ $\mathrm{J}_{\text {pad., }}$ specific consumption of these substances $\mathrm{V}_{\mathrm{i} p} . \mathrm{V}_{\text {pad. }}$ and even fire extinguishing normative time $\mathrm{T}_{\mathrm{n}}$.

It is obvious that using such normative parameters, in its turn, would allow easily elaborate the objective numerical indicators for fire extinguishing efficiency, extinguishing solid burning materials and even numerical indicators for extinguishing quality - comparing the numerical value of a definite fire extinguishing efficiency indicator with normative value of this indicator.

As it was noted in the works of previous researchers, knowing the numerical value of the specific consumption for all kinds of combustible substances and materials, you can calculate the consumption of necessary extinguishing substance seconds $q_{\text {nep }}(\mathrm{l} / \mathrm{s})$, their supply intensity $J_{\text {nep }}, J_{\text {pad }}$ $\left(1 / \mathrm{m}^{2} \times \mathrm{s}\right)$, specific consumption at a fire extinguishing area unit $V_{\bar{p}},\left(1 / \mathrm{m}^{2}\right)$ and total stocks of extinguishing substances that are necessary for all the time of fire extinguishing, i.e., all the basic parameters of fire extinguishing process [4]. The specific comsumption of extinguishing substances $V_{\bar{i} p}, \quad\left(1 / \mathrm{m}^{2}\right)$ and extinguishing time $T_{d z}$, (s), the most important parameters of fire extinguishing, can be considered as the main indicators of the fire extinguishing efficiency. These parameters allow to have an objective judgement about real efficiency of ordinary fire extinguishing. Consequently, it possible to elaborate scientific principles for the construction of automatic fire extinguishing systems with optimal parameters, as well as obtain the objective criteria of fire extinguishing quality and increase the efficicency of fire fighting at objects of national economy $[6,8]$.

\section{Assessment Methods for Extinguishing Capacity of Surfactants and Water}

In the practical part of the article the mixtures of water and surfactants Vacht 2, protein Sthamex AFFF 6\%, FP-70; Tridol S6; synthetic Sthamex AFFF 3\%, Tridol S3, protein and synthetic foam concentrate mixture Karate MB-5 3\% (synthetic) mixture with Sthamex AFFF 6\% (protein); Vacht 2 (protein) mixture with Tridol S3 (synthetic), Sthamex AFFF $6 \%$ (protein) mixture with Sthamex AFFF 3\% (synthetic); Vacht 2 (protein) mixture with Tridol S3 (synthetic); FP-70 (protein) mixture with Tridol S6 (synthetic); efficiency assessment by extinguishing fires of combustible substances and highly inflammable liquids.

Equipment and Materials Used in Practical Study, Description of Experiment Place:

Practical part of the study was implemented at the Faculty of Engineering Economics and Management, Laboratory of Labour and Civil Protection Institute (fire safety research laboratory No. 10) of Riga Technical University. A special space (closed space) is arranged in the laboratory auditorium, which is finished with incombustible materials (hereinafter referred to as specially arranged space).

There is an experimental stationary fireextinguishing system (automatic fire-extinguishing system), one-directional, connected to a closed tank; the sprinkler Tyco TY-FRB TY-3131 Upright, 5.6 KFactor of fine sprayer (upward), minimum working pressure $0.07 \mathrm{Mpa} 1$ piece.

System capacity estimate was carried out in accordance with technical parameters of automatic fire-extinguishing system (Table 2).

Sprinkler Tyco Ty-Frb Ty-3131(Directed Upwards) Capacity Calculation Table

\begin{tabular}{|l|l|l|l|l|l|l|}
\hline $\begin{array}{c}\text { Estimate } \\
\text { method }\end{array}$ & Protected area & $\begin{array}{c}\text { Water } \\
\text { consumpti } \\
\text { on }\end{array}$ & $\begin{array}{c}\text { Required minimal } \\
\text { pressure (pump } \\
\text { parameters }\end{array}$ & $\begin{array}{c}\text { Water } \\
\text { delivery rate }\end{array}$ & $\begin{array}{c}\text { Minimal } \\
\text { flow rate }\end{array}$ & $\begin{array}{c}\text { Number of } \\
\text { sprayers }\end{array}$ \\
\hline Request & $\left(\mathrm{m}^{2}\right)$ & $(1 / \mathrm{min})$ & $($ bar $)$ & $\left(1 / \mathrm{min} / \mathrm{m}^{2}\right)$ & $(1 / \mathrm{min})$ & Unit \\
\cline { 2 - 7 } & 12 & 60 & 2.38 & 0.55 & 60 & 1 \\
\hline
\end{tabular}

Upon practical implementation of connection diagram, working pressure in the system was 1.9 $\mathrm{MPa}$, water consumption was estimated proportionally based on data obtained in the program; as a result, output of sprinkler used in practical experiment was $47.89 \mathrm{l} / \mathrm{min}$ or $0.7983 \mathrm{l} / \mathrm{min}$, the results coincided in practical test with minimal relative error [10].

The following mixtures were prepared having a certain concentration: (Table 3 ) 
Types and Combinations of Mixtures Used in Practical Experiment

\begin{tabular}{|c|l|c|}
\hline Nr.p.k. & \multicolumn{1}{|c|}{ Extinguishing substance } & Concentration (\%) \\
\hline 1. & Water & - \\
\hline 2. & Water & - \\
\hline 3. & Water & - \\
\hline 4. & Water & - \\
\hline 5. & Water & - \\
\hline 6. & STHAMEX®-AFFF 6\% (Prot.) & $3 \%$ \\
\hline 7. & STHAMEX®-AFFF 6\% (Prot.) & $3 \%$ \\
\hline 8. & STHAMEX®-AFFF 6\% (Prot.) & $2 \%$ \\
\hline 9. & Vacht 2 (Prot.) & $0.25 \%$ \\
\hline 10. & FP-70 (Prot.) & $0.50 \%$ \\
\hline 11. & STHAMEX®-AFFF 3\% (Synth.) & $3 \%$ \\
\hline 12. & Tridol S3 (Synth.) & $0.25 \%$ \\
\hline 13. & Tridol S3 (Synth.) & $0.25 \%$ \\
\hline 14. & Tridol S6 (Synth.) & $0.25 \%$ \\
\hline 15. & STHAMEX®-AFFF 6\% (Prot.)+STHAMEX®-AFFF 3\% (Synth.) & $3 \%$ \\
\hline 16. & Karate MB-5 3\% (Synth.)+STHAMEX®-AFFF 6\% (Prot.) & $2 \%$ \\
\hline 17. & Vacht 2 (Prot.)+Tridol S3 (Synth.) & $0.50 \%$ \\
\hline 18. & FP-70 (Prot.)+Tridol S6 (Synth.) & $0.50 \%$ \\
\hline 19. & Vacht 2 (Prot.)+Tridol S3 (Synth.) & $0.25 \%$ \\
\hline
\end{tabular}

A steel pan with legs wherein solid substance was burnt had been installed in the specially arranged space (hereinafter referred to as specially arranged space) where burning of solid combustible materials was done. The steel pan dimensions: $0.5 \times 0.5 \times 0.1 \mathrm{~m}$, leg height $0.1 \mathrm{~m}$, metal screen with 0.05 mesh is arranged in the pan base. The pan $0.5 \times 0.5 \times 0.05 \mathrm{~m}$ wherein solid liquid was burnt was installed under the metal screen. The amount of the wood burnt was $1 \mathrm{~kg}$.
The steel pan with legs wherein highly inflammable liquids were burnt was installed in the specially arranged space. The steel pan parameters: Dn $0.6 \mathrm{~m}$, depth $0.25 \mathrm{~m}$. The metal screen with 0.05 mesh is arranged in the pan base. The pan $0.5 \times 0.5 \times 0.05 \mathrm{~m}$, leg height $0.25 \mathrm{~m}$, was installed under the metal screen.

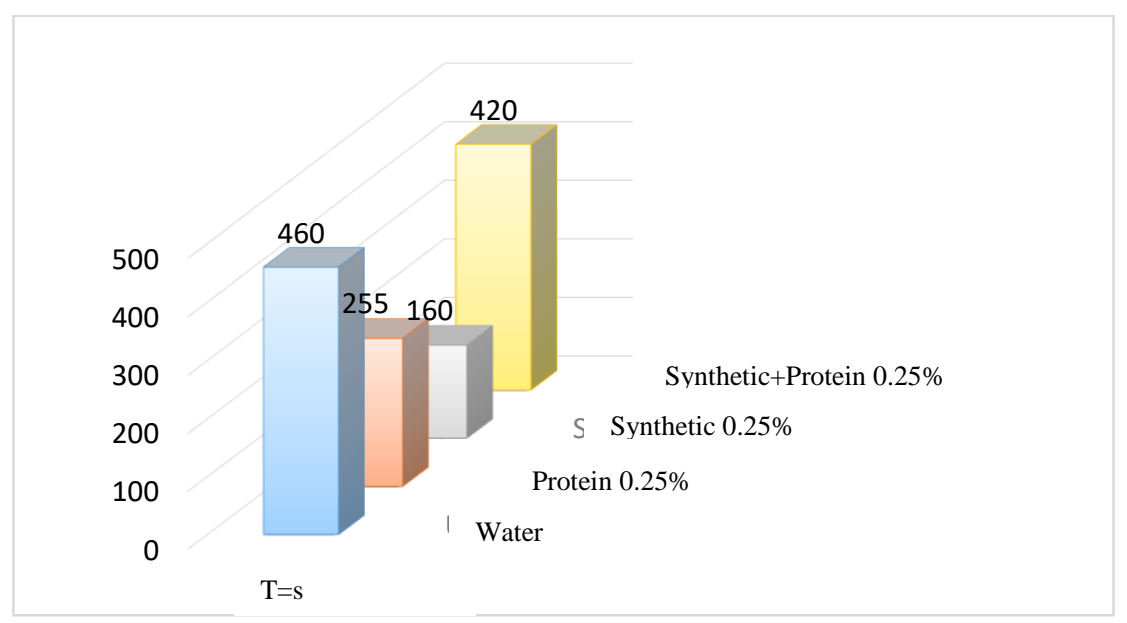

Fig. 1. Class A fire extinguishing time (s) at solution concentration $0.25 \%$

Simulation and extinguishing of class A and B fires were carried out in the experimental part, using a stationary fire-extinguishing system and an upward sprinkler with $5.6 \mathrm{~K}$-Factor as a sprayer. Water and modified water with addition of surface-active agents were delivered for extinguishing. Foam concentrates on protein and synthetic base were used as quenchers. Surfactants were delivered in different concentrations. Mixtures of surfactants, where synthetic and protein-based surfactants were mixed, were used as well. Water solutions with $0.25 \%$ to $3 \%$ ratio of surface-active agents were used in the fire extinguishing experiment. The results obtained were analysed and summarized in the table (see Fig.1). The analysis of the obtained results, namely, the fire extinguishing time with the use of $0.25 \%$ admixture extinguishing solution, showed that the fire was most rapidly extinguished with the use of synthetic concentrate, the time being 160 seconds (Figure 1). 
The analysis of the obtained results, namely, the average fire extinguishing time with the use of $0.25 \%$ to $3 \%$ admixture extinguishing solution, showed that the fire was most rapidly extinguished with use of synthetic foam concentrate. Average extinguishing time was 247 seconds (Figure 2).

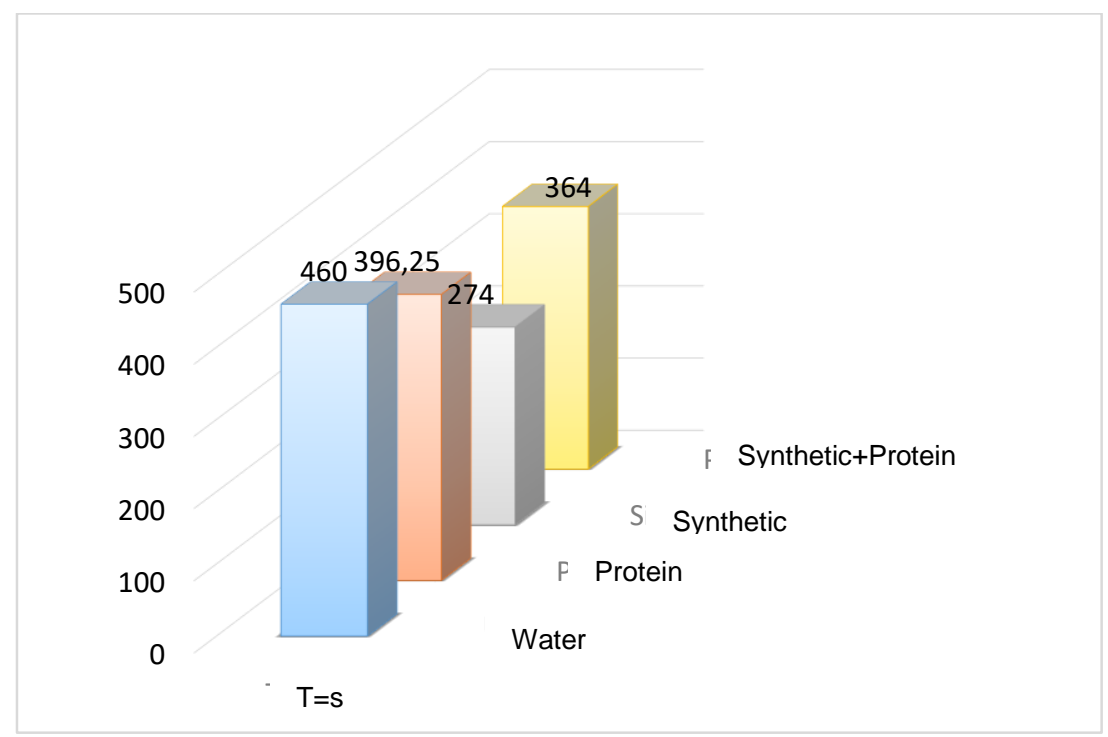

Fig. 2. Class A fire average extinguishing time (s) at solution concentration 0.25 to $3 \%$.

The analysis of the obtained water consumption results with the use of $0.25 \%$ admixture extinguishing solution showed that the least extinguishing liquid amount spent for fire extinguishing was with the use of synthetic foam concentrate. 127 litres of extinguishing solution were used (Table 4).

TABLE 4

The Data Acquired During the Practical Experiment

\begin{tabular}{|c|c|c|c|c|c|c|c|c|c|c|c|}
\hline Nr. & $\begin{array}{l}\text { Extinguishing } \\
\text { substance }\end{array}$ & 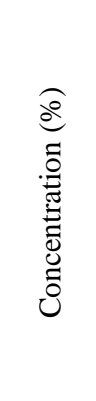 & 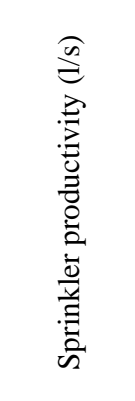 & 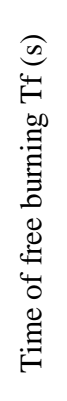 & 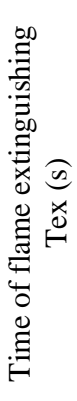 & 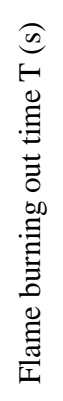 & 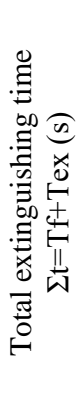 & 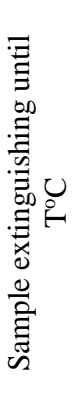 & 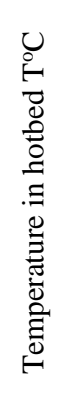 & 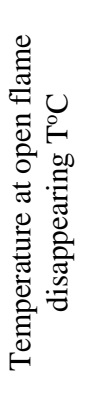 & 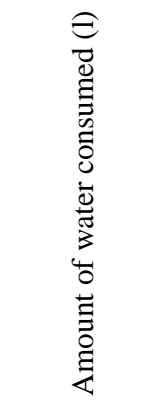 \\
\hline 1. & Water & - & 0.798319 & 180 & 460 & & 640 & 50 & 490 & - & 367.22674 \\
\hline 2. & Water & - & 0.798319 & 180 & 460 & & 640 & 50 & 765 & - & 367.22674 \\
\hline 3. & Water & - & 0.798319 & 180 & 220 & 310 & 400 & 200 & 620 & 445 & 175.63018 \\
\hline 4. & Water & - & 0.798319 & 180 & 180 & 300 & 360 & 180 & 820 & 180 & 143.69742 \\
\hline 5. & Water & - & 0.798319 & 180 & 170 & 320 & 350 & 200 & 842 & 200 & 135.71423 \\
\hline 6. & $\begin{array}{c}\text { STHAMEX® } \\
\text {-AFFF 6\% } \\
\text { (Prot.) }\end{array}$ & $3 \%$ & 0.798319 & 180 & 460 & - & 640 & 50 & 760 & - & 367.22674 \\
\hline 7. & $\begin{array}{l}\text { STHAMEX® } \\
\text {-AFFF 6\% } \\
\text { (Prot.) }\end{array}$ & $3 \%$ & 0.798319 & 180 & 480 & - & 660 & 50 & 553 & - & 383.19312 \\
\hline 8. & $\begin{array}{c}\text { STHAMEX®) } \\
\text {-AFFF 6\% } \\
\text { (Prot.) }\end{array}$ & $2 \%$ & 0.798319 & 180 & 390 & 480 & 570 & 200 & 890 & 450 & 311.34441 \\
\hline 9. & $\begin{array}{c}\text { Vacht } 2 \\
\text { (Prot.) }\end{array}$ & $0.25 \%$ & 0.798319 & 180 & 255 & 350 & 435 & 200 & 670 & 480 & 203.571345 \\
\hline 10. & FP-70 (Prot.) & $0.50 \%$ & 0.798319 & 180 & 280 & 440 & 460 & 50 & 820 & 70 & 223.52932 \\
\hline
\end{tabular}


TABLE 4 CONTINUED

\begin{tabular}{|c|c|c|c|c|c|c|c|c|c|c|c|}
\hline Nr. & $\begin{array}{l}\text { Extinguishing } \\
\text { substance }\end{array}$ & 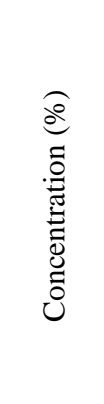 & 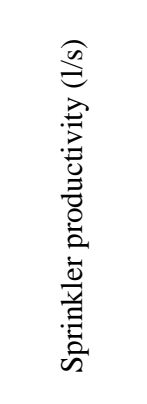 & 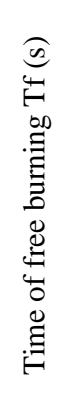 & 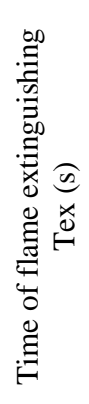 & 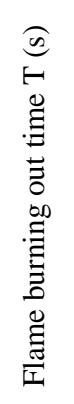 & 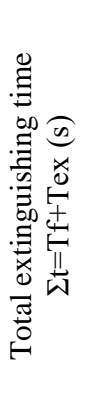 & 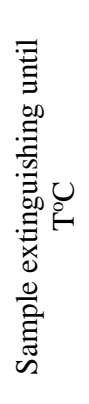 & 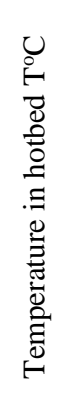 & 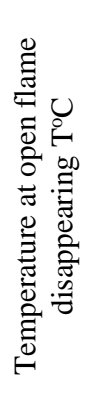 & 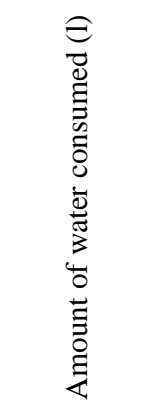 \\
\hline 11. & $\begin{array}{c}\text { STHAMEX® } \\
\text {-AFFF 3\% } \\
\text { (Synth.) }\end{array}$ & $3 \%$ & 0.798319 & 180 & 360 & - & 540 & 50 & 580 & & 287.39484 \\
\hline 12. & $\begin{array}{c}\text { Tridol S3 } \\
\text { (Synth.) }\end{array}$ & $0.25 \%$ & 0.798319 & 180 & 240 & 410 & 420 & 70 & 720 & 420 & 191.59656 \\
\hline 13. & $\begin{array}{c}\text { Tridol S3 } \\
\text { (Synth.) }\end{array}$ & $0.25 \%$ & 0.798319 & 180 & 160 & 340 & 340 & 40 & 725 & 40 & 127.73104 \\
\hline 14. & $\begin{array}{c}\text { Tridol S6 } \\
\text { (Synth.) }\end{array}$ & $0.25 \%$ & 0.798319 & 180 & 330 & 390 & 510 & 200 & 690 & 430 & 263.44527 \\
\hline 15. & $\begin{array}{c}\text { STHAMEX® } \\
\text {-AFFF 6\% } \\
\text { (Prot.)+STHA } \\
\text { MEX®-AFFF } \\
3 \% \text { (Synth.) }\end{array}$ & $3 \%$ & 0.798319 & 180 & 560 & 500 & 740 & 50 & 836 & - & 447.05864 \\
\hline 16. & $\begin{array}{c}\text { Karate MB-5 } \\
3 \% \\
\text { (Synth.)+STH } \\
\text { AMEX®- } \\
\text { AFFF 6\% } \\
\text { (Prot.) } \\
\end{array}$ & $2 \%$ & 0.798319 & 180 & 240 & 380 & 420 & 200 & 720 & 360 & 191.59656 \\
\hline 17. & $\begin{array}{c}\text { Vacht 2 } \\
\text { (Prot.)+Tridol } \\
\text { S3 (Synth.) }\end{array}$ & $0.50 \%$ & 0.798319 & 180 & 180 & 300 & 360 & 200 & 820 & 400 & 143.69742 \\
\hline 18. & $\begin{array}{c}\text { FP-70 } \\
\text { (Prot.)+Tridol } \\
\text { S6 (Synth.) }\end{array}$ & $0.50 \%$ & 0.798319 & 180 & 420 & 600 & 600 & 50 & 857 & 50 & 335.29398 \\
\hline 19. & $\begin{array}{c}\text { Vacht 2 } \\
\text { (Prot.)+Tridol } \\
\text { S3 (Synth.) }\end{array}$ & $0.25 \%$ & 0.798319 & 180 & 420 & 600 & 600 & 30 & 897 & 30 & 335.29398 \\
\hline
\end{tabular}

\section{Conclusions:}

1. Concentration of active surfactants in water directly affects fire-extinguishing properties of liquids, i.e., observing the amount of surfactants and water liquids - concentration - one can achieve the reduction of the amount of water, which allows to reduce material loss connected with using water in fire extinguishing.

2. Correct concentration of surfactants and water liquid affect the amount of water used for fire extinguishing and its effect on material values, which allows to reduce material loss caused by water used for fire extinguishing.

3. The use of surfactants and water liquid significantly reduces the temperature in a hotbed, which allows to reduce material loss caused by temperature.

4. The use of surfactants and water liquid significantly reduces not only the temperature in a hotbed, but also reduces smoldering in the combustion area, which allows to reduce material loss caused by temperature.

5. The use of surfactants and water liquid significantly reduces not only the temperature and smoldering in a hotbed, but also reduces smoke in a hotbed, which allows to reduce material loss caused by temperature and the convective smoke flow.

6. The use of surfactants and water liquid significantly reduces water consumption for fire extinguishing purposes, which allows to save drinking water supplies and resources, since fire fighting water supply system is usually combined with the drinking water supply system.

7. Taking into account the amount of water used for extinguishing $1 \mathrm{~kg}$ of wood and the amount of actually consumed water, we can conclude that an in-depth study must be carried out to find out how 
economically profitable is the use of SAA for fire extinguishing.

References

1. V. Jemeljanovs. Ėku iekšējo ugunsdrošības üdensapgādes sistēmu efektivitātes paaugstināšana. Autoreferāts disertācija inženierzinātnu doktora zinātniskā grāda iegūušanai. - Riga: RTU, 1998. - 20 p.

2. M. Ziemelis Promocijas darbs "UGUNS DZËŠANAS AR ŪDENI EFEKTIVITĀTES PAAUGSTINĀŠANA" Rīgā 2009., 100 lpp.

3. World Fire Statistics. Report No.21. -Center of Fire Statistics of CTIF, 2016. - 62 lpp.

4. 22 $2^{\text {nd }}$ International Scientific Conference, Economics and Management 2017 (ICEM 2017) hosted by Riga Technical University, May 10-12, 2017 Riga, Latvia Vladimirs Jemeljanovs, Georgijs Kiselovs, Jelena Malahova "Improvement of water fire-extinguishing capability by use of foam agents, surfactants and mixtures thereof".

5. Мартынов Е.С., Девкин А.П. Установки автоматического пожаротучения перегретой воды // Безопасность труда в промышиленности., ч.2 - М.: Недра, 1992. - стр. 16.

6. Исследование новых смачивателей и пенообразователей на основе производственного сырья. Отчет Свердловской ПЖС. Свердловск: ПЖС, 1966. - стр. 90.

7. Исследование влияния добавок на огнегосительные свойства вобы. Отчет по теме 2- 86-70 ВНИИПО МВД-М.: ВНИИПО, 1972. - 64 стр.

8. Дягилева Л.К., Казаков М.В.,Одинец М.В. Влияние добавок на огнегосительные свойства воды// Сб. науч. тр. № 12. - М.: ВНИИПО, 1972. -80 стр.

9. Казаков М.В., Демидов П.Г. Применение смачивателей для тушения пожаров. -М.: Стройиздат, 1964. - стр. 54.

10. Agnis Andžāns, Jānis Čakste, Tomass Larfelds, Līga Ramāna, Mārīte Seile VIDE $\bar{E} \bar{A} S V \bar{E} R T \bar{I} B A S$ METODE 218. lpp.

11. Jemeljanovs A. Lielmolekulāro vielu izmantošana ugunsdzēsības praksēl/ LR Ugunsdzēsības pārvaldes informatīvais zinātniski tehniskais biletetens, Nr. 5. - Rīga: Ugunsdzēsības pārvalde, 1993. - 7.- 8. lpp.

12. Зельдович Я.Б. Математическая теория горения и взрыва. Москва, Наука, 1980.

13. http://libraryno.ru/7-2-gorenie-drevesiny-teorgorandbax/ Прочеe / Теория горения и взрыва / 7.2. Горение древесины. 